\title{
Teaching Twentieth Century American History Topics Through the Rearview Mirror of Motorsports
}

\author{
Joyce A. Young \\ Indiana State University \\ Lisa Phillips \\ Indiana State University
}

Over the last forty years, motorsports has grown to become one of the most popular spectator sports in the United States, second only to professional football. Often motorsports reflected the narratives of the times. The authors of this article, one a historian and one a business professor, teamed up to teach an interdisciplinary history course at a Midwestern university that combined aspects of U.S. history and motorsports. The university offered an interdisciplinary program in motorsports management housed in the College of Business. The course earned foundational studies credit under the historical studies category and was available to all undergraduate students. As a result of enrolling and completing the course, students often demonstrated an even higher level of interdisciplinary learning and American history recall than expected by the two instructors.

Keywords: interdisciplinary learning, American history, motorsports, course development

\section{INTRODUCTION}

Over the last forty years, motorsports has grown to become one of the most popular spectator sports in the United States, second only to professional football. Since the turn of the nineteenth century, Americans and international drivers have raced on two and four wheels and drawn throngs of fans to dirt tracks, public roads, board tracks, sandy beaches, purpose-built tracks, and city streets. Often motorsports reflected the narratives of the times. The authors of this article, one a historian and one a business professor, teamed up to teach an interdisciplinary history course at a Midwestern university that combined aspects of U.S. history and motorsports.

The university offered an interdisciplinary program in motorsports management housed in the College of Business. The course earned foundational studies credit under the historical studies category and was available to all undergraduate students. The pedagogical approach used the applied context of motorsports to introduce, discuss, and reinforce important U.S. history topics related to the twentieth century. Though using a motorsports context is novel, using sports to understand American history is not (Laliberte, 2013). This article describes the teaching methods, the resources that are available, and challenges of offering a history/motorsports interdisciplinary course. A course outline is also included in the article for interested instructors. 


\section{THE VALUE OF INNOVATIVE, INTERDISCIPLINARY COURSES}

Interdisciplinary instruction is the integration of two or more disciplines of study (Jacob, 2015). According to Carlaton University (n.d), an interdisciplinary pedagogical approach leads to greater critical thinking and cognitive development. Baloche, Hynes, \& Berger (1996) suggest interdisciplinary instruction can broaden a student's "capacity to understand multiple viewpoints on a given topic or between disciplines." Elements of significant learning are commonly seen in interdisciplinary pedagogy, such as foundational knowledge, application, and integration (Fink, 2003). Each of these three elements are present in the course design discussed below.

\section{COURSE DESIGN}

The content of the course covers nine distinct eras of American history in the twentieth century that closely follows thirteen chapters in the textbook America: A Narrative History - Volume 2 by David Emory Shi and George Brown Tindall (2016). We also selected corresponding motorsports readings from various sources which related to each of the eras. Below, we present a brief discussion of many major themes seen in American history as reflected in motorsports. The review is not an exhaustive list and there are topics that encompass sequential eras. In some instances, course content focused on a given moment in time to prevent overlapping assignments.

\section{Nationalism, Manifest Destiny, Masculinity, and the New Leisure Class (1895-1910)}

Nation building placed the United States in direct competition with other countries such as Britain, Germany, France, and Italy. The competition carried over into motorsports through automobiles, tracks, and events (Cofaigh, 2011). The Gordon Bennett trophy in Europe and the Vanderbilt Cup, held on Long Island in New York State, brought vehicles from many nations to race on public roads to show the superiority of their machines and the competitiveness of their auto industries. Men risked life and limb in the pursuit of extreme speed and glory. Eventually, a backlash against racing on public roads with hundreds of thousands of spectators in harm's way led to the use of purpose-built tracks such as the Indianapolis Motor Speedway in the U.S. (Burns, 2006).

Most racers in the era were wealthy men who easily afforded the cost of a racing vehicle. Automobiles were the toys of the elite and, to some, a symbol of growing class inequality of the era. Yet, at the same time, also symbolic of the US' growing influence on the world's stage. William K. Vanderbilt, the greatgrandson of Cornelius Vanderbilt, the railroad titan, created the Vanderbilt Cup, America's first international auto race (Burns, 2006). Events also occurred in other wealthy resort communities, such as Atlantic City and Cape May, New Jersey and Ormond and Daytona Beach, Florida.

\section{Progressivism and the Great War}

The expansion of motorsports during the Progressive era was either evidence of a growing U.S. economy, the ills that plagued the country, or both. The 500 Mile race at the Indianapolis Motor Speedway with its brick surface was first held in 1911 and offered the richest payday in sports (Gifford, 2006). Racing on the sandy beaches in Florida was popular. Though older fairground dirt tracks did double duty for horses and automobiles, purpose-built tracks were quickly constructed throughout the country. Board tracks, viewed as a great technological innovation, made from wood planks were increasingly popular and could be found in states such as California, Washington, Illinois, Ohio, Nebraska, Iowa, and Pennsylvania (Simone, 2009). Built in 1915, Twin City Speedway in Minnesota was the first major U.S. superspeedway with a concrete surface. Racing eventually fragmented into two segments: 1) dirt, the focus of local drivers and the everyday man and 2) non-dirt events, preferred by professionally sanctioned drivers and elites. Racing was incredibly dangerous and deadly. Cars often lacked brakes, ran on unsuitable tires, and were mechanically unreliable (Gifford, 2006). If a safety helmet was worn, it provided no real protection for the driver (Gifford, 2006). Racing circuits and surfaces were even more deadly with ruts, dust, trees, pedestrians and passenger car traffic (Gifford, 2006). 
Motorsports was a male dominated field, though females did race. The nation's attention to women's suffrage subtly encouraged some to push the envelope in male-dominated arenas. Joan Cuneo, known as "the woman who got women banned from racing" was a fearless, top level racer (Nystrom, 2013). After several wins, the Automobile Manufacturers Association convinced the American Automobile Association (AAA) to ban all women from its sanctioned competition races in $1909 .{ }^{12}$ With Europe engulfed in World War I and the U.S. joining in 1917, interest in racing waned as attention turned to the war effort. European drivers were unavailable and races were shortened or stopped altogether during the war years. With no racing at the Indianapolis Motor Speedway, the facility served as a military airstrip for plane repair and refueling (Kramer, 2009).

\section{The Roaring Twenties and Advances in Technology}

The end of World War I brought great prosperity to the US and a whole and to motorsports in particular. Racing grew throughout the country, though predominately on dirt and board tracks, with emerging regional distinctions in terms of car type (Simone, 2009). Fuel technologies, such as tetraethyl lead and corn-based ethanol, were introduced (Simone, 2009). In 1928, the World's Land Speed Record was reclaimed for by Ray Keech on Daytona Beach at 207.55 miles per hour (Kreitzer, 2015).

As in the Progressive era, racing did not roar for everyone. Moonshine runners in their fast cars surfaced during Prohibition as a means of economic survival for southern men and their families (Clark, 2008). When not hauling alcohol, the men were racing their stock cars on dirt tracks. Women were still banned from competitive racing and African Americans, though not formally banned from racing, were also turned away from AAA sanctioned racing (Gould, 2019). The Indianapolis Motor Speedway was segregated African Americans were not permitted to attend or participate in its events (Gould, 2019). As a result, a group of black entrepreneurs, along with several white financiers, created the Colored Speedway Association in 1924 and its Gold \& Glory Sweepstakes - a racing series for African American drivers and mechanics based in Indiana (Gould, 2019).

Cars, driving, rum-running, and racing were inextricably linked. Prosperity seemed limitless for many and just a dream for others. Whether sporting events, food, drink, appliances, labor saving devices, the modern American consumer emerged in this era driving his or her own Model T.

\section{The Great Depression and the Rise of Adolph Hitler}

The Great Depression reinforced the regional perspective of racing based on geographical location, such as stock cars in the South and midgets in the West. Drivers lacked the funds to travel beyond their home regions and many racing companies declared bankruptcy (Simone, 2009). The Indianapolis 500 was an exception as it maintained its national and international draw (Kramer, 2009). The WPA projects of the New Deal unexpectedly led to a new round of track building.

In the Northeast, sports car racing thrived on open roads and The Vanderbilt Cup reemerged in 1936 despite the depression woes. The 1937 Vanderbilt Cup welcomed Adolf Hitler's Mercedes-Benz and Auto Union race cars. Their presence in the U.S. provoked massive anti-German demonstrations (Reuss, 2008). Hitler's cars dominated in Europe and foreshadowed his march toward world superiority. In front of 80,000 spectators, 29 drivers representing 5 countries (including 23 Americans) witnessed the Vanderbilt Cup win by German driver, Bernd Rosemeyer in his Auto Union car (Smellman, 2002).

\section{World War II and Post War Prosperity}

Racing in the U.S was not immune from sacrifice during the war. As a result, the U.S. government banned motorsports in its effort to conserve rubber, fuel, and metal (Simone, 2009). Post war brought another round of track expansion and greater interest in motorsports. The 1950s represented the all-time peak in U.S. racing circuits (Simone, 2009). The diversity of new tracks included dirt, asphalt, short, drag strips, former military airfields, road courses, and super speedways such as the Daytona Speedway. Professional sanctioning bodies were created to govern specific forms of racing such as NASCAR for stock cars, the NHRA for drag racing, USAC for open wheel, and the SCCA for European-styled sports cars favored by military veterans returning from England, France, Germany, and Italy (Simone, 2009). 
NASCAR's dominance into the next century resulted from seeds planted in the 1950s. From its origin, the sport adopted a business philosophy to entertain fans rather than racing simply for sport or technological advancements (Shackleford, 2011). Stock cars closely resembled production-based cars that consumers drove on a daily basis and the NASCAR promoted "consistent racing action between closely matched cars" (Shackleford, 2011). As the era closed, the racing disaster involving spectators at the 24 hours of Le Mans in France and numerous racing deaths in the U.S, led the American Manufacturers Association to end its factory support of the sport (Gifford, 2006). NASCAR was hardest hit by the decision since it relied heavily on close relationships with the car manufacturers.

\section{The Civil Rights Era and Urban Sprawl}

The track building boom from the 1950s continued into the 1960s. NASCAR was the primary benefactor. The France family which owned NASCAR took a marked different approach to race track ownership - they built and owned many tracks, through their majority-owned International Speedway Corporation, giving NASCAR a degree of control that no other sanctioning body could claim,. New tracks included Rockingham, North Carolina and Talladega, Alabama (Young, 2010). Other new NASCAR tracks, not owned by the family, were located in the outlying areas of Atlanta, Bristol, Tennessee, and Charlotte (Young, 2010). Urban sprawl in the North claimed many dirt tracks and resulted in a decline of dirt track racing (Simone, 2009). New tracks built were asphalt replacements located away from population centers.

The regionalism of racing in the 1930s resurfaced in the 1960s and reinforced the racism and segregation of the South. Case in point is the story of Wendell Scott - the first African American driver that raced at the top level in NASCAR, the Grand National Series (Donovan, 2008). He struggled to find sponsorship and was often turned away from tracks due to his skin color. He earned the most points for a rookie driver in 1961, but the Rookie of the Year award was given to the runner up, a white driver. In 1963, he won a Grand National race at Jacksonville, Florida. The track refused to recognize his win and awarded the trophy to the second place finisher, a white driver. NASCAR went several years before acknowledging his race win.

\section{Cigarette Advertising, Environmentalism, and Feminism}

With its 1969 Public Health Cigarette Smoking Act, the U.S. Congress banned cigarette advertising from television and radio broadcast media. Overnight, U.S tobacco producers, such as R. J. Reynolds and Philip Morris, needed alternative outlets for their over 200 million dollars in annual advertising spending or risk decreased exposure to consumer markets (Yost 2007). Big tobacco turned to motorsports sponsorships. NASCAR's Grand National Series became the Winston Cup; USAC created the Marlboro Championship Cup - which included the Indianapolis 500; the NHRA changed to the NHRA Winston Drag Racing Series; and in sport cars, the SCCA L\&M Continental 5000 Championship was created (Simone, 2009).

The OPEC oil embargo led many people to call for a ban on racing during the energy shortage. NASCAR and its founder, Bill France, Sr., led the racing industry in organizing opposition. They argued that motorsports was an economic engine employing thousands of people throughout the U.S. The argument worked and the sport was permitted to "develop and adopt its own conservation measures" (Simone, 2009). Though, races were shortened, postponed, and cut, the show went on. The motorsports industry also received an exemption from the regulations enacted by the 1970 Clean Air Act, thus allowing the industry continued use of tetraethyl lead based fuels despite its high toxicity levels (Simone, 2009).

In 1977, Janet Guthrie made her second attempt to qualify and race in the Indianapolis 500. She was welcomed by many fans, but hatefully rejected by others. Sexism was on full display in the U.S. mail and in the grandstands. In her failed attempt to qualify in 1976, she received a letter that contained the following passage: "You are clearly either a neuter or a lesbian.... a phony, ugly, non-talented inarticulate, man-hating, money-grubbing, hypocritical bitch" (Guthrie, 2005). She endured death threats and constant jeers. In 1977, a man seated directly behind her pit stall held up a sign that said: "Janet Grab the Pole" - it was accompanied 
by a graphic of a barber-pole striped phallus (Guthrie, 2005). Guthrie prevailed in 1977 to become the first female to race at the Indianapolis 500.

\section{Growing Consumerism}

The R. J. Reynolds tobacco company brought its marketing expertise to motorsports. It had created the first "show cars" - former race cars used to promote its sponsorship of various race teams. Other sponsors learned from the company's success and began similar promotional activities. In the 1980s, lots of teams and sponsors, across all types of racing, maintained show cars that traveled throughout the U.S. to attract race fans to various locations, typically retail stores associated with a sponsor's product (Yost, 2007).

More diversified sponsors, beyond tobacco and beer, not only spent millions of dollars to have their names and logos on race cars, they spent millions more to leverage their initial sponsorship investment to engage race fans when they were away from the track. If a show car was sitting in a grocery store parking lot, it was a sure bet that the brand was on sale inside the store. Sponsors also tied their television advertising to their sponsorship endeavors when possible. Taken as a whole, the effort drove new levels of consumer spending and consumption, attendance at tracks, and viewership on television. For NASCAR, the strategy was so successful that its fans were more likely to purchase its sponsors' brands than in any other sport (Roccu, 2005).

\section{The Economic Boom and Big Business}

Motorsports had become big business as the turn of the century approached. Money continued to pour into the industry as television viewership and attendance increased. Four new, virtually identical, 1.5 mile oval asphalt tracks - known as "cookie cutters tracks" - were built around the country in Dallas, Kansas City, Las Vegas, and Miami (Yost, 2007). Two large racing organizations, International Speedway Corporation - majority owned by NASCAR's France family, and Speedway Motorsports, Inc., were responsible for the expansion push (Yost, 2007). The tracks took on characteristics of other major sporting venues with sponsor suites, gift shops, and other fan amenities. Roger Penske built a 2 mile asphalt oval near Los Angeles. Four other 1 mile asphalt ovals were built near Chicago, Colorado Springs, outside St. Louis, and Loudon, New Hampshire (Young, 2010). Most of the new tracks hosted top level NASCAR and Indycar races. Other types of racing series did not experience significant track expansion.

\section{COURSE ACTIVITIES}

The course used a module approach to deliver content comprised of 9 distinct eras in American History (as shown in the Appendix). Various pedagogical tools were developed including connection questions, quizzes, book reports, and experiential learning events.

\section{Connection Questions}

Nine weekly writing assignments entitled Connection Questions were created to bring together the reading content from book chapters, journal articles, dissertation chapters, books and YouTube. They served as the basis for lectures and class discussion with a specific focus on how American history was depicted through motorsports in a given era. The assignments were submitted to the instructors at the beginning of each module discussion.

\section{Weekly Quizzes}

At the end of each class session, a 25-item multiple choice quiz was administered to students to access their knowledge of the assigned module. The questions addressed the reading assignments for the given week. There was a mix of American history and motorsports questions.

\section{Book Reports}

Two book reports were assigned for the sixteen week academic term. As listed below, the Gould book is set in the 1920s and documents the racism and discrimination faced by African American drivers and 
mechanics. The Guthrie book focuses on the endeavors of the first woman to race in the Indianapolis 500 in 1977.

Gould, Todd (2002). For Gold \& Glory: Charlie Wiggins and the African-American Racing Car Circuit. Bloomington, IN: Indiana University Press.

Guthrie, Janet (2005). Janet Guthrie: A Life at Full Throttle. Toronto, Canada: Sport Media Publishing.

Though not book reports, students also read material from two additional books worthy of more indepth attention. The second set of books, listed below, can be switched for the first set or the instructor can use all four titles for book reports by dividing students among the two sets. If the instructor chooses to use the second set for book reports rather than the first set, we recommend that he/she replace the book chapter readings with content from each of the first two books. The Donovan book documents the life of the first African American to race in NASCAR's top series, the Grand National, in the 1960s. The Nystrom book tells the story of one of America's first female racers in the early 1900s.

Donovan, Brian (2008). Hard Driving: The Wendell Scott Story. Hanover, NH: Steerforth Press.

Nystrom, Elsa A. (2013). Mad for Speed: The Racing Life of Joan Newton Cuneo. Jefferson, NC: McFarland \& Company.

\section{Class Participation}

For the semester, the students were placed in assigned class discussion groups for the entirely of each night. The instructors designed the groups to ensure diversity of major, class level, gender, and motorsports management minors. Together, they reviewed their individual answers to the connection questions and then created a best answer to the given question to present to the class. Groups then evaluated all of the presentations and then voted for the best overall effort for the class. A group was not allowed to vote for its own presentation. Class participation was also assessed in relation to a student's attendance at guest speaker nights, as well as the field trip.

\section{Experiential Learning Events}

During the semester, four guest speaker events and one field trip were completed. For the given semester, two book authors, Brian Donavan and Janet Guthrie, traveled to campus to spend the day with the class and students enrolled in the university's motorsports studies program.

Two members of USAC, a driver and an executive of the organization, met with the class, followed by two members of the NHRA, a driver and a track manager. Thus, students heard first-hand accounts from an author who documented the life of NASCAR's Wendell Scott; Indycar's Janet Guthrie, herself, the first woman to race in the Indy 500; and long-time USAC and NHRA participants that were living history voices.

The class also took a field trip to the Indianapolis Motor Speedway Museum and met with the Donald Davidson, the long-time historian of the Indianapolis Motor Speedway. He shared highlights of his career, history of the track and its races, and answered students' questions.

\section{DISTRIBUTION OF POINTS EARNED}

Shown below in Table 1 were the available points for each aspect of the course. Allowing students to drop their lowest score on Connection Questions submissions and Weekly Quizzes was supportive of not only the students but also the instructors in terms of less time creating makeup assignments. 
TABLE 1

\section{COURSE ASSIGNMENTS}

\begin{tabular}{lc}
\hline Assignment & Points \\
\hline Connection Questions (9@25 points each - lowest score dropped & 200 \\
Weekly Quizzes (9@25 points each - lowest score dropped & 400 \\
Book Reports (2@150 points) & 300 \\
Class Participation & 100 \\
\hline Total Points & 1000
\end{tabular}

\section{FEEDBACK ON COURSE}

A diverse mix of 62 students enrolled in the course (taught once a week), in terms of majors and minors, class level, and gender ( $38 \%$ female). Among the minors, there were ten motorsports management students. One student who needed an open elective to finish his major degree was interviewed by a reporter doing a story about the class from a major Indianapolis television station. He described his perception, which mirrored the opinion of most students, of the course:

"Then the motorsports [aspect] sold me. It's challenging. You have to be there in class, you have to read [a lot], you have to study in order to keep up with the class, but they arranged it that way. Everybody has to get something out of it. Everybody has to be able to take history and correlate it into motorsports of that era" (Arceo 2011).

Based on the scores earned on module assignments, students often demonstrated an even higher level of interdisciplinary learning and American history recall than expected by the two instructors. The student evaluation ratings of instruction for the course were also impressive. On a five-point scale, $66 \%$ of students rated the course a 1 , the best score possible, on the level of understanding of the subject matter. The mean score was a 1.66 .

\section{CHALLENGES FACED}

Striking the appropriate balance between American history content and motorsports content is a daunting task. The instructor must accept at least a 50-50 split or possibly a 40-60 split favoring motorsports. Regardless, many worthy topics from both domains will not be covered. The objective of the course is to strive to connect as many important points in time in twentieth century American history with documented supporting history from motorsports.

We strongly believe that during the twentieth century, motorsports was a microcosm of American history. As such, we selected the leading narrative history textbook which is easy to read and contains interesting personal stories - a similar approach used in the majority of the selected motorsports readings.

We were fortunate to have two instructors from two different colleges at the university to agree to team teach the course. Together, they carefully crafted all aspects of the course to interconnect the two content areas. The knowledge required to teach the course may not exist in a single instructor, however, the materials provided in Appendix A will go the distance in preparing the instructor for the course.

We also succeeded in building an impressive list of experiential learning events. Instructors at other universities may feel this is not possible based on geographical locations. Luckily, racetracks and race teams, many of which have rich histories to share, are located throughout the country. Also, for a relatively small financial investment, some book authors are willing to travel to campus. Instructors may also consider inviting Daniel Simone, the present Curator of the NASCAR Hall of Fame, located in Charlotte, North Carolina, whose dissertation served as our initial catalyst in conceptualizing the course. 


\section{CONCLUSION}

Using a motorsports context to understand twentieth American history is a novel approach. As demonstrated in the discussion above, motorsports was a microcosm of American history and reflected the narratives of the times. Given the interdisciplinary approach implemented in the course, many students were more engaged by the course content than a typical silo-focused history course. As a result of enrolling and completing the course, students often demonstrated an even higher level of interdisciplinary learning and American history recall than expected by the two instructors.

\section{REFERENCES}

Arceo, A. (2011, May 9). Indy 100: New Class Combines Century of Racing, U.S. History. Retrieved from https://www2.indstate.edu/news/news.php?newsid=2753

Baloche, L., Hynes, J., \& Berger, H. (1996). Moving Toward the Integration of Professional and General Education. Action in Teacher Education, 1(8), 1-9.

Burns, J. (2006). Thunder at Sunrise: A History of the Vanderbilt Cup, the Grand Prize and the Indianapolis 500, 1904-1916. Jefferson, NC: McFarland \& Company.

Carlaton University (n.d). Why Teach with an Interdisciplinary Approach? Science Education Resource Center at Carleton College. Retrieved from https://serc.carleton.edu/econ/ interdisciplinary/why.html

Clark, L. (2008). One Helluva Ride: How NASCAR Swept the Nation. New York: Villard Books.

Cofaigh, É. (2011). Motor Sport in France: Testing-ground for the World. The International Journal of the History of Sport, 22(2), 191-204.

Donavan, B. (2008). Hard Driving: The Wendell Scott Story. Hanover, NH: Steerforth Press.

Fink, L. (2003). Creating Significant Learning Experiences. San Francisco, CA: Jossey Bass.

Gifford, C. (2006). Racing: The Ultimate Motorsports Encyclopedia. Boston: Kingfisher.

Gould, T. (2002). For Gold \& Glory: Charlie Wiggins and the African-American Racing Car Circuit. Bloomington, IN: Indiana University Press.

Guthrie, J. (2005). Janet Guthrie: A Life at Full Throttle. Toronto, Canada: Sport Media Publishing.

Jacob, J. (2015, January 20). Interdisciplinary trends in higher education. Palgrave Communications. https://doi.org/10.1057/palcomms.2015

Kramer, R. (2009). Indianapolis Motor Speedway: 100 Years of Racing. Iola, WI: Krause Publications.

Kreitzer, A. (2015). Speed Bugs: American Motorsports and the Pursuit of Speed 1926-1932. The Society for the History of Technology. Retrieved from http://www.technologystories.org/speed-bugsamerican-motorsports-and-the-pursuit-of-speed-1926-1932/

Laliberte, D. (2013). Foul Lines: Teaching Race in Jim Crow America through Baseball History. The History Teacher, 10(3), 329-353.

Nystrom, E. (2013). Mad for Speed: The Racing Life of Joan Newton Cuneo. Jefferson, NC: McFarland \& Company.

O'Kane, P. (2011). A History of the 'Triple Crown' of Motor Racing: The Indianapolis 500, the Le Mans 24 Hours and the Monaco Grand Prix. The International Journal of the History of Sport, 28(2), 281-299.

Reuss, E. (2008). World Domination on the Racetrack. Hitler's Motor Racing Battles: The Silver Arrows under the Swastika. Somerset, UK: Haynes Publishing.

Rocco, M. (2005, July 9). More Fortune 500s Shift to NASCAR. Fox Business. Retrieved from https://www.foxbusiness.com/features/more-fortune-500s-shift-to-nascar

Shackleford, B. (2011). NASCAR Stock Car Racing: Establishment and Southern Retrenchment. The International Journal of the History of Sport, 28(2), 300-318.

Shi, D., \& Tindall, G. (2016). America: A Narrative History - Volume 2. New York: W. W. Norton \& Company. 
Simone, D. (2009). Racing, Region, and the Environment: A History of American Motorsports. Ann Arbor, MI: ProQuest.

Smellman, L. (2002). 1937: The Golden Era of Grand Prix Racing. Retrieved from http://www.kolumbus.fi/leif.snellman/gp373.htm\#2

Yost, M. (2007). The 200-MPH Billboard: The Inside Story of How Big Money Changed NASCAR. St. Paul, MN: Motorbooks.

Young, J. (2010). The IndyCar Series: A Marketing Channels Perspective. International Journal of Sport Management and Marketing, 18(1/2), 57-72.

\section{APPENDIX}

\section{COURSE CONTENT OUTLINE}

\section{Nationalism, Manifest Destiny, Masculinity, and the New Leisure Class (1895-1910)}

Book Chapter: Shi \& Tindall (2016), Chapter 20 - Seizing an American Empire, 1865-1913

Journal Article: Cofaigh, Éamon Ó. (2011). Motor Sport in France: Testing-ground for the World. The International Journal of the History of Sport, 28(2), 191-204.

Book Chapter: Burns, John M. (2006). Thunder at Sunrise: A History of the Vanderbilt Cup, the Grand Prize and the Indianapolis 500, 1904-1916, (pp. 7-82). Jefferson, NC: McFarland \& Company.

YouTube Video: 1903 Gordon Bennett Trophy (Running time $=1: 44$ minutes) https://www.youtube.com/watch?v=fkMOyHu56Gg

Connection Question: In 1908, you are assigned the task of staging a major racing event in the U.S. Use your knowledge of U.S. racing and American history in this era to design and describe your event in great detail. You must include content from all assigned readings.

Quiz: Knowledge and understanding of American history topics for the era.

\section{Progressivism and The Great War}

Book Chapter: Shi \& Tindall (2016), Chapter 21 - The Progressive Era, 1890-1920

Shi \& Tindall (2016), Chapter 22 - America \& the Great War, 1914-1920

Book Chapter: Nystrom, Elsa A. (2013). Banished! Mad for Speed: The Racing Life of Joan Newton Cuneo, (pp. 119-133). Jefferson, NC: McFarland \& Company.

Journal Article: O'Kane, Philip (2011). A History of the 'Triple Crown' of Motor Racing: The Indianapolis 500, the Le Mans 24 Hours and the Monaco Grand Prix. The International Journal of the History of Sport, 28(2), 281-299.

Dissertation Chapter: Simone, Daniel J. (2009). Places, Spaces, and Races: The Beginning, (1895-1918). In Racing, Region, and the Environment: A History of American Motorsports, (pp. 26-49). Ann Arbor, MI: ProQuest.

YouTube Video: 1911 Historic Indy 500 Newsreel (Running time $=3: 28$ minutes)

https://www.youtube.com/watch?v=DObRkFU6-Rw 
Connection Question: How did the Great War influence the development of motorsports in the U.S.? What technological advancements in auto racing came about during this era? Discuss. You must include content from all assigned readings.

Quiz: Knowledge and understanding of American history topics for the era.

\section{The Roaring Twenties and Advances in Technology}

Book Chapter: Shi \& Tindall (2016), Chapter 23 - A Class of Cultures, 1920-1929

Shi \& Tindall (2016), Chapter 24 - The Reactionary Twenties

Journal Article: Kreitzer, Alison (2015). Speed Bugs: American Motorsports and the Pursuit of Speed 1926-1932. The Society for the History of Technology. http://www.technologystories. org/ speed-bugs-american-motorsports-and-the-pursuit-of-speed-1926-1932/

Dissertation Chapter: Simone, Daniel J. (2009). Minor Leagues, Fuel, and the Great Depression, (1919-1944). In Racing, Region, and the Environment: A History of American Motorsports, (pp. 50-64). Ann Arbor, MI: ProQuest.

YouTube Video: The Forgotten Race - Seg. 2 (Running time $=8: 15$ minutes) https://www.youtube.com/watch?annotation_id=annotation_2720583445\&fea ture $=$ iv\&src_vid $=$ NiEZssNgFQA\& $\&=$ xl-dJf-9RFI

Connection Question: Speed records and automobile races were important symbols of modernity and progress in this period of American history. Yet, not all Americans flourished during this era. Describe how motorsports depicted both perspectives. You must include content from all assigned readings.

Quiz: Knowledge and understanding of American history topics for the era.

Book Report: Gould, Todd (2002). For Gold \& Glory: Charlie Wiggins and the African-American Racing Car Circuit. Bloomington, IN: Indiana University Press.

\section{The Great Depression and the Rise of Adolph Hitler}

Book Chapter: Shi \& Tindall (2016), Chapter 25 - The Great Depression, 1929-1939

Dissertation Chapter: Simone, Daniel J. (2009). Minor Leagues, Fuel, and the Great Depression, (1919-1944). In Racing, Region, and the Environment: A History of American Motorsports, (pp. 64-77). Ann Arbor, MI: ProQuest.

Book Chapter: Reuss, Eberhard (2008). World Domination on the Racetrack. In Hitler's Motor Racing Battles: The Silver Arrows under the Swastika, (pp. 190-253). Newbury Park, CA: Haynes Publishing.

YouTube Video: The Vanderbilt Cup (1937) (Running time $=1: 22$ minutes)

https://www.youtube.com/watch?v=hJM-R93BthA

Pause at 53 seconds for the German swastika on the Auto Union cars.

Connection Question: The Great Depression reinforced a regional perspective across the U.S. and led to a diversity of types of racing based on geographical location. As a result, describe the racing 
preferences in 1) the Northeast, 2) the Midwest, 3) the South, and the West. You must include content from all assigned readings.

Quiz: Knowledge and understanding of American history topics for the era.

\section{World War II and Post War Prosperity}

Book Chapter: Shi \& Tindall (2016), Chapter 26 - The Second World War, 1933-1945

Shi \& Tindall (2016), Chapter 27 - The Cold War and the Fair Deal, 1945-1952

Shi \& Tindall (2016), Chapter 28 - Cold War America, 1950-1959

Journal Article: Shackleford, Ben (2011). NASCAR Stock Car Racing: Establishment and Southern Retrenchment. The International Journal of the History of Sport, 28(2), 300-318.

Dissertation Chapter: Simone, Daniel J. (2009). If You Build It, They Will Race (1945-1955). In Racing, Region, and the Environment: A History of American Motorsports, (pp. 78-109). Ann Arbor, MI: ProQuest.

YouTube Video: 1956 Darlington Southern 500 (Running time $=24: 58$ minutes) https://www.youtube.com/watch?v=DzoVAh2zLqU

Connection Question: By some, the 1950s have been described as the "good old days" of racing in the U.S. You are assigned the task of staging a major racing event in the U.S. in 1958. Use your knowledge of racing and American history in this era to design and describe your event in great detail. You must include content from all assigned readings.

Quiz: Knowledge and understanding of American history topics for the era.

\section{The Civil Rights Era and Urban Sprawl}

Book Chapter: Shi \& Tindall (2016), Chapter 29 - New Frontier \& a Great Society, 1960-1968

Book Chapter: Donovan, Brian (2008). Hard Driving: The Wendell Scott Story, (pp. 93-135). Hanover, NH: Steerforth Press.

Dissertation Chapter: Simone, Daniel J. (2009). Superhighways, Sprawl, and Superspeedways (1956-1969). In Racing, Region, and the Environment: A History of American Motorsports, (pp. 110-130). Ann Arbor, MI: ProQuest.

YouTube Video: Wendall Scott (Running time $=4: 07$ minutes) https://www.youtube.com/watch?v=_qTgUJaO5B0

Connection Question: Identify and discuss the challenges that Wendell Scott faced as he pursued his racing career in NASCAR. Are his experiences representative of civil rights struggles during this era, as well as the overall changes occurring across the U.S.? Discuss. You must include content from all assigned readings.

Quiz: Knowledge and understanding of American history topics for the era. 


\section{Feminism, Environmentalism, and Cigarette Advertising}

Book Chapter: Shi \& Tindall (2016), Chapter 30 - Rebellion and Reaction, 1960s and 1970s

Dissertation Chapter: Simone, Daniel J. (2009). Petroleum and Pollutants, (1970-1979). In Racing, Region, and the Environment: A History of American Motorsports, (pp. 150-178). Ann Arbor, MI: ProQuest.

Book Chapter: Yost, Mark (2007). From Rags to Riches - Junior Johnson Turns Tobacco into Gold. In The 200-MPH Billboard: The Inside Story of How Big Money Changed NASCAR, (pp.7397). St. Paul, MN: Motorbooks.

YouTube Video: IndyCar driver Janet Guthrie says 'I'm a woman, so what?'

(Running time $=6: 26$ minutes)

https://www.youtube.com/watch?v=oSTYRt5TcCU

Connection Question: What had changed in the U.S. to make it acceptable for Janet Guthrie to participate in the Indianapolis $500 \ldots$ or did Janet Guthrie break through the gender barrier despite the ultra-masculine nature of motorsports? What other influences changed the face of racing during this era? Discuss. You must include content from all assigned readings.

Quiz: Knowledge and understanding of American history topics for the era.

Book Report: Guthrie, Janet (2005). Janet Guthrie: A Life at Full Throttle. Toronto, Canada: Sport Media Publishing.

\section{Reaganomics and Growing Consumerism}

Book Chapter: Shi \& Tindall (2016), Chapter 31 - Conservative Revival, 1977-1990

Book Chapter: Yost, Mark (2007). The Sponsorship Shepards - Four Hundred Cases of Coffee and a Side of Viggy. In The 200-MPH Billboard: The Inside Story of How Big Money Changed NASCAR, (pp. 99-121). St. Paul, MN: Motorbooks.

Trade Article: Rocco, Matthew (2015, July 9). More Fortune 500s Shift to NASCAR. Fox Business. Retrieved from https://www.foxbusiness.com/features/more-fortune-500s-shift-tonascar

YouTube Video: NASCAR Sponsors - Why They Invest (Running time $=3: 18$ minutes) https://www.youtube.com/watch?v=c8WVMqP78fg

Connection Question: Throughout the century, motorsports continued to evolve. In this era, the sport was now driven by fans (viewership, attendance, product purchases) rather than drivers and teams or automobile manufacturers. Discuss as it relates to consumerism. You must include content from all assigned readings.

Quiz: Knowledge and understanding of American history topics for the era. 


\section{The Economic Boom and Big Business}

Book Chapter: Shi \& Tindall (2016), Chapter $32-21^{\text {st }}$ Century America, 1993-Present

Book Chapter: Yost, Mark (2007). When NASCAR Comes to Town - How Much is that Track in the Midwest. In The 200-MPH Billboard: The Inside Story of How Big Money Changed NASCAR, (pp.147-170). St. Paul, MN: Motorbooks.

Journal Article: Young, Joyce A. (2010). The Indycar Series: A Marketing Channels Perspective. International Journal of Sport Management and Marketing, 8(1/2), 57-72.

YouTube Video: International Speedway Corporation - Power https://www.youtube.com/watch?v=Z5ISfhovdZM

Connection Question: As the $20^{\text {th }}$ century closed, motorsports was no longer viewed as a sport but rather big business. Has the new prospective changed the focus of racing? Discuss. You must include content from all assigned readings.

Quiz: Knowledge and understanding of American history topics for the era. 